\title{
THE ROLE OF ENTREPRENEURIAL ORIENTATION IN PRODUCT INNOVATION IN EMERGING MARKETS ON THE LOCAL PRODUCTS
}

\author{
Vivy Kristinae ${ }^{\star}$, Roby Sambung, Meitiana Sahay \\ University of Palangka Raya, Faculty of Economics and Business, Indonesia \\ vivykristinae84@gmail.com \\ robysambung@gmail.com \\ meitiana.sahay@gmail.com
}

\begin{abstract}
This research is to improve product development with resource-based innovation that is based on the competitive advantage of local product SMEs with an initial market orientation and the role of mediating entrepreneurial skills and driving skills. This study is based on product cases in the domestic market and develops markets for local SME products with interviews and quantitative methods in 30 Small and Medium Enterprises in Central Kalimantan with PLS SEM analysis tools. The findings in this study included identifying and supporting mediating roles. Entrepreneurial orientation towards product innovation in increasing proactive knowledge and risk-taking, innovative market-oriented ideas in product innovation. This research only has results and research units from the scale of local SME products and then for research and theoretical research can be examined on a large scale with additional literature on market orientation. The research implications of research and analysis in product research in local products with market orientation and entrepreneurial orientation can increase revenue and sales, SMEs can implement EO as an important role after market control to improve innovation products and as a strategy in competition with cultural values. The novelty in research is the contextual business strategy and the theory of RBV in a significant positive competitive advantage from EO support in local SME product innovation
\end{abstract}

Keywords: Market orientation, Entrepreneurial Orientation, Product Innovation, SME Local Products.

JEL classification: O31, D24, L26.

\section{Introduction}

Small and Medium Enterprises (SME) are moving rapidly and continuously in emerging markets such as in Indonesia in local products in the direction of full challenges in the current era (Zohdi et al., 2013). Business Opportunities that can survive in the crisis that occurred in Indonesia in early 2002 and 2018 data show that $65 \%$ of SME have survived in the last 3 years in Central Kalimantan, the most recent province in Indonesia (Setyanti et al., 2013). Continuous success based on business (Siringoringo et al., 2013) is that local products will survive when they are able to innovate, rejuvenating products at maturity as a business strategy to survive in the efforts of non-local products.

Many literatures have views on human resources and resource-based theory (RBV) as the basis of capability in product innovation and adopt the definition of resources as including assets in organizational capabilities and processes, company attributes, information and knowledge so that SMEs are controlled. by markets that allow them to develop and implement strategies that increase efficiency as sustainable capabilities in emerging markets (Wu, 2013). Market orientation (MO) provides a value of efficiency and

\footnotetext{
* Corresponding author: Vivy Kristinae
} 
effectiveness, and ultimately drives the performance of product innovation (Wong, 2012). This definition is broad in product innovation and when, if its nature includes capabilities and expertise that are strategically related to companies that are not resources, $M O$ is not necessarily strong in product innovation (Yu et al., 2016). Abdulai Mahmoud and Yusif (2012) suggest that companies that innovate and engage in entrepreneurship can survive with competitive advantages on products. By offering innovative products, companies can sometimes avoid price competition, access new marketing, and make new requests, and improve the company's business performance as indicated by financial metrics such as turnover, profits, and stock prices and or develop strength in strategic metrics such as reputation, loyalty, and satisfaction (Tohidi and Jabbari, 2012).

In product innovation expertise as an entrepreneurial orientation is positively related because innovation has a positive effect on business performance (Zhang et al., 2014). However, market orientation shows a negative effect on business performance, due to the lack of proactive and risk-taking elements in the market orientation dimension in the strength of the multi-channel business in the local product market with innovation as an idea. Generation in SME (Baker et al., 2009) its role in business strategy MO but market orientation does not significantly affect product innovation (Kocak A, 2017, Yu et al., 2016). The strong relationship of $\mathrm{MO}$ influences the $\mathrm{EO}$ as a positively related variable (Inic and Petrovic, 2012, Boso et al., 2016, Line and Wang, 2016, Pitchayadol et al., 2018) using the RBV theory in research and becomes the basis of the EO with the dimensions of Proactiveness, Risk taking, and Innovative Idea in Mediating the relationship of MO (Vega-Vázquez et al., 2016, Haryanto, 2017) with product innovation (Newman, 2016). Based on research gaps and strategies to improve product development, this study aims to examine the role of EO in mediating $\mathrm{MO}$ and product innovation in local SME products in Central Kalimantan, Indonesia.

\section{Literature review}

\subsection{Product Innovation (PI)}

Sharma et al. (2016) emphasize the fact that little attention has been devoted to the influence of innovation, customer orientation, and entrepreneurial orientation on corporate performance and it is also important to consider innovation in one particular sector in product products such as product innovation. Product innovation is a process that includes: technical design, research and development, production, management, and commercial activities related to marketing new products (Sok and O'Cass, 2015). Product innovation is part of the innovation process into the initiation stage and the implementation phase with an important part of the initiation stage is openness to product innovation, which is determined by whether the product craftsman is willing to consider adopting a purposeful product innovation activity to improve management efficiency to maintain human resource strategies with customer needs and see the life of the product survive in the market from competitors (Nuryakin, 2018).

Product innovation performance is a factor used to measure product and product performance in innovation must be differentiated based on time and cost (Pan and Li, 2016). The benefits of product innovation in product development that product innovation must be determined by the cost and time of the project so that it can be effective and efficient for customers, the ability to compete with competitors with internal coordination (Yang and Yang, 2015). Measuring costs and time objectively (Ozkan-Canbolat et al., 2016) and subjectively can show the success of product innovation performance in product development. 


\subsection{Market Orientation (MO)}

MO has been defined by marketing researchers as a framework for improving product sustainability and competitive advantage (AH Affendy, 2015). In some studies, MO is a strategy with market orientation as a focus on latent needs that leads to insight into the demands of customers and for more commitment to the development of innovation products and services (Abdulai Mahmoud and Yusif, 2012). Based on this approach, (Boso et al., 2012) distinguishes two constructs of innovation: innovation and the capacity to innovate. They also observed that innovation contributes to the company's capacity to innovate, that is, to implement new ideas, processes, or products with Market Orientation (Carbonell and Rodríguez Escudero, 2010). Innovation is very helpful to be improved as a fulfillment of customer demands for products through customer orientation and making a line of challenges in competitor orientation (Han et al., 1998, Abdulai Mahmoud, 2012). Diversity of innovation products can finally survive with the innovation of the MO with the dimensions of consumer orientation and competitor orientation and requires shared willingness within the organization consistently analyzes the competitive environment. The relative role of business actors in the market can actively target customer-oriented with high-level innovation capabilities that can develop innovative services and products in accordance with changes in the market environment during differences business cycle phase (Adhikari and Gill, 2011).

\section{Market Orientation in Product Innovation}

$\mathrm{MO}$ as a basis for business research in the value chain shows that actors in each segment focus on the value chain to serve the needs of key customers and coordinate strategically with value propositions in a vertically and horizontally coordinated marketing system as a business strategy (Beneke et al., 2016). The responsive dimensions of market orientation in businesses that adopt responsive $\mathrm{MO}$ are focused on valuing customer needs articulated by serving segments or markets, and then continually increasing the value of products or services served by actors through product innovation (Boso et al., 2012). The importance of inter-functional coordination to be superior to customers mentioned in various studies that focus on positive effects on product development (Ejdys, 2015). The positive relationship between market orientation and customer satisfaction is almost default because SMEs who have a basis for market orientation are to find and meet customer needs and have a theoritical research competitive advantage (Augusto and Coelho, 2009).

Market orientation by defining product innovation capabilities as the ability to keep changing with knowledge and ideas into products, new processes and systems with customer orientation and competitor orientation provides evidence to show a positive relationship between innovation capabilities in product innovation (Ata, 2018), while coordinating with innovation capabilities high level can develop innovative services and products to address environmental changes during different business cycle phases with coordination capabilities (Day, 2000, Brashear et al., 2012).Therefore, we put forward the following in the hypothesis: H1: Is there a positive and significant Market Orientation to the EO?

$\mathrm{H} 2$ : is there a positive and significant influence on the role of Market Orientation on PI?

\subsection{Entrepreneurial Orientation (EO)}

Entrepreneurship is very important as one of the marketing disciplines that emphasizes marketing is home to the entrepreneurial process in organizations (Adeniran and Johnston, 2012). In addition, entrepreneurship interacts with internal and external relations in SME (Al-Dhaafri and Al-Swidi, 2016). Rational factors for generating business results, not driving performance independently (Balodi, 2016) with an entrepreneurial orientation are seen as important additional processes in business through ideas in innovation and results on a small business scale. Many orientation and market learning orientations are developed, business people / craftsmen tend to defend them by involving entrepreneurial orientation variables as the relationship between ideas and performance tends to persist in various 
contexts (Deniz, 2016). The focus of entrepreneurship is one of the market based elements that influence innovation leading to product innovation is the implementation of a product or service with improved performance performance characteristics that provide objectively new or better (Caseiro and Coelho, 2018).

\section{Entrepreneurial Orientation towards product innovation}

Innovation is an important organizational capability, because the success of new products is the engine of growth that gives and impacts on increasing sales, profits, and competitiveness for many organizations (Jin et al., 2017). Product or service innovation will not mean much if it does not achieve commercial success (Jin and Cho, 2018). Companies must develop the ability to market new products or services with the ability to entrepreneurship with three indicators of Proactiveness, risk taking and inter and Entrepreneurship coordination is a dynamic process of capability and skills in product innovation can generate profit (Jalilvand et al., 2017). Wealth is created by individuals who bear the main risk, in the form of capital, time, and commitment to career risk in terms of providing value to products or services because it is the ability to take risks in decision making on EO (Amin et al., 2016). Product innovation that are applied to EO methods by business people through efforts to achieve and allocate the skills and resources and from the view of some experts, it can be concluded that entrepreneurship is the ability to think creatively and act innovatively as a basis for product innovation (Alireza et al., 2014, Aljanabi, 2018). Our second hypothesis is as follows:

H3: Are there positive and significant influences on the role of EO Mediation on Product Innovation?

\section{Methodology and Data}

This research uses a quantitative method with SEM partial least square (PLS) analysis tool (Bauer and Auer-Srnka, 2012, Dilger et al., 2017). Quantitative testing is done to test field data taken based on theoretical and empirical studies, test the validity and reliability of indicator relationships and latent variables (external models or measurement models), and relationships between variables which end with testing research hypotheses or structural models. Using a questionnaire developed based on theoretical and empirical research relevant to research variables (MO, EO and $\mathrm{PI}$ ). Quantitative analysis is done using the SEM equation model based on partial leas square (PLS). Data does not have to be normally distributed, it can be used for variable analysis with good formative reflective indicators, and can be used to analyze the relationship between variables with a minimum sample of 30 for the field of multivariate data analysis in management and strategy with descriptive analysis (Hair et al., 2011).

Research Location of Small and Medium Enterprises (SME) local batik cloth products in Palangkaraya City, Province. State of Central Kalimantan Indonesia. The types of data used are questions and data analysis (quantitative) sourced from as many as 30 SMEs with typical batik products from Central Kalimantan. Methods of data collection: 1 . Surveys, this method of selecting SMEs is the focus of research to see and analyze data used for at least 5 years and based on 2. Direct interviews on site to ensure samples can be trusted in the selection of research locations and contextual indicators the research and quality of batik cloth products are recognized by the Department of Trade and Industry of Central Kalimantan Province. 3. questionnaires, in the form of a list of questions submitted based on indicators (literature and interviews) are easily understood by business actors whose receipts are 40-60 years old. and, 4. Sampling techniques Based on local products, Central Kalimantan batik cloth as a sample. This study uses a minimum sample for analysis and uses Partial Least Square (PLS) analysis tools, so it can predict the relationship between variables with a minimum sample size of 30 (Hair et al., 2010). 


\section{Research result}

The results of the study show that the relationship in the study is strong and influencing each variable indicator and based on the statistical results with PLS SEM shows the results:

Table 1: Outer Loading

\begin{tabular}{|c|c|c|}
\hline Variable & Indicators & Outer Loading \\
\hline \multirow{3}{*}{ Market Orientation } & MO.1 & 0.710 \\
\cline { 2 - 3 } & $\mathrm{MO} .2$ & 0.835 \\
\cline { 2 - 3 } & $\mathrm{MO} .3$ & 0.858 \\
\hline \multirow{2}{*}{$\begin{array}{c}\text { Entrepreneurial } \\
\text { Orientation }\end{array}$} & $\mathrm{EO} .1$ & 0.944 \\
\cline { 2 - 3 } & $\mathrm{EO} .2$ & 0.717 \\
\cline { 2 - 3 } & $\mathrm{EO} .3$ & 0.788 \\
\hline Product Innovation & $\mathrm{PI} .1$ & 0.706 \\
\cline { 2 - 3 } & $\mathrm{PI} .2$ & 0.716 \\
\cline { 2 - 3 } & $\mathrm{PI} .3$ & 0.897 \\
\hline
\end{tabular}

Based on the best correlation in the Market Orientation variable questionnaire, MO.2 (Competitor Orientation) and MO.1 (Consumer Orientation) of $0.640>0.5$ (AVE) and the cross-loading relationship between MO.3 variables (Interfirm Coordination) shows a 0.858> 0.7 loading is strong in the influence of the relationship with $\mathrm{EO}$ and $\mathrm{PI}$. In the Entrepreneurial Orientation variable, the best correlation in the EO.2 variable (Risk taking) and EO.1 (Proactive) is equal to 0.817> 0.5 (AVE) even though the small EO3 (Innovativeness) remains significant for $\mathrm{PI}$ and in cross loading relationships and a positive relationship between EO.1 (Proactiveness) variables has $0.944>0.7$ largest outer loading in relation to $\mathrm{PI}$. In the PI variable the value of PI.3 (Products are better than competitors) and PI.2 (Modification of product capabilities) has the best correlation of $0.797>0.5$ (AVE) and in external loading PI.3 (Products better than competitors) have the biggest influence between variables, but PI.1 (product design capacity) also exceeds $0.706>0.7$ in the smallest outer loading value in the product innovation variable shows a good relationship between variables.

Table 2: Cross Loading

\begin{tabular}{|c|c|c|c|}
\hline \multirow{2}{*}{ Indicators } & \multicolumn{3}{|c|}{ Variabel } \\
\cline { 2 - 4 } & $\begin{array}{c}\text { Market } \\
\text { Orientation }\end{array}$ & $\begin{array}{c}\text { Entrepreneurial } \\
\text { Orientation }\end{array}$ & $\begin{array}{c}\text { Product } \\
\text { Innovation }\end{array}$ \\
\hline MO.1 & 0.640 & 0.307 & 0.571 \\
\hline MO.2 & 0.579 & 0.318 & 0.420 \\
\hline MO.3 & 0.510 & 0.463 & 0.486 \\
\hline EO.1 & 0.411 & 0.741 & 0.471 \\
\hline EO.2 & 0.673 & 0.692 & 0.436 \\
\hline EO.3 & 0.566 & 0.817 & 0.619 \\
\hline PI.1 & 0.472 & 0.378 & 0.631 \\
\hline PI.2 & 0.379 & 0.561 & 0.813 \\
\hline PI.3 & 0.317 & 0.406 & 0.797 \\
\hline
\end{tabular}


Table 3: Average Variant Extracted (AVE)

\begin{tabular}{|c|c|c|c|}
\hline Variable & AVE $(\mathbf{> 0 , 5 )}$ & $\begin{array}{c}\text { Composite } \\
\text { Reliability }(\mathbf{0}, \mathbf{6})\end{array}$ & $\begin{array}{c}\text { Cronbach's } \\
\text { Alpha }\end{array}$ \\
\hline Market Orientation & 0.517 & 0.817 & 0.832 \\
\hline $\begin{array}{c}\text { Entrepreneurial } \\
\text { Orientation }\end{array}$ & 0.572 & 0.893 & 0.864 \\
\hline Product Innovation & 0.514 & 0.864 & 0.821 \\
\hline
\end{tabular}

Next, in answering the hypothesis by testing the goodness of the model in testing the $R$-square value and the t-statistical test can be accepted if $p$-value is $<0.05$. based on the data in the hypothesis test table show:

Table 4: T-Statistics and P-Value Hypotesis

\begin{tabular}{|c|c|c|c|c|c|}
\hline & Influence & R-Square & T-Statistics & P-value & Results \\
\hline $\mathrm{H} 1$ & $\begin{array}{l}\text { Is there a positive and } \\
\text { significant Market } \\
\text { Orientation to the EO }\end{array}$ & 0.446 & 5.103 & 0.000 & Accepted \\
\hline $\mathrm{H} 2$ & $\begin{array}{l}\text { is there a positive and } \\
\text { significant influence on the } \\
\text { role of Market Orientation } \\
\text { on PI }\end{array}$ & 0.521 & 7.681 & 0.000 & Accepted \\
\hline $\mathrm{H} 3$ & $\begin{array}{l}\text { Are there positive and } \\
\text { significant influences on } \\
\text { the role of EO Mediation } \\
\text { on Product Innovation }\end{array}$ & 0.353 & 3.714 & 0.024 & Accepted \\
\hline
\end{tabular}

On the AVE value, the average variance of each variable shows the mean sample value> 1.96 , meaning valid and reliable with an average of $50 \%$ of $97.5 \%$ data confidences as well as questionnaire data biased less than $10 \%$ and based on the matrix above the direct relationship novelty $\mathrm{EO}$ on $\mathrm{PI}$ in each activity greatly influences and is needed in addition to policies in decision making and innovative idea generation, proactiveness in $\mathrm{PI}$ when positive and negative values are diagrams with high frequencies contributing to the maturity of the product. The results of the analysis in this study suggest that $\mathrm{EO}$ in mediating $\mathrm{MO}$ and $\mathrm{PI}(\mathrm{H} 1)$ results were significant and strong in direct $\mathrm{MO}$ compared to $\mathrm{PI}(\mathrm{H} 2)$ even though the results were significantly positive. Whereas $\mathrm{H} 3$ has a significant positive effect of $\mathrm{MO}$ to be antecedent EO to PI. SME in Central Kalimantan in developing local products is important to sharpen methods with EO so that good Product Innovation can improve business sustainability and can be a business strategy for product development with entrepreneurial human resources (Chen et al., 2012) assets. In this study denied the gap on the capability theorists seek to explain how combinations of resources and capabilities can be developed and deployed in response to dynamic business environments (Teece et al., 1997, Ngo and O'Cass, 2012, Yu et al., 2016) based on emerging market results is a significant positive result of $\mathrm{MO}$ on $\mathrm{PI}$ and states that this research is in line with related Product Innovation based on market research through MO will increase sale growth and can develop products better because based on consumer orientation, competitor orientation and good coordination interface (Yu et al., 2016).

\section{Conclusion}

The sustainability of small and medium enterprises in local products that are culturally valuable with Product Innovation can increase revenue and support the government in gaining foreign exchange (Chen et al., 2014) because SME is a small business that has a 
product unique (Yuan and Chen, 2015, Açıkgöz et al., 2016, Fernandez-Mesa et al., 2013) product philosophy (Chahal et al., 2016) that will not be eroded by the digitalization era MO (Morgan et al., 2016). MO and PI will get positive added value if SME can improve Human Resources knowledge and skills through EO (Vega-Vázquez et al., 2016) in product innovation (modification of forms so that fashion updates, adjusting price and quality, maintaining the quality of cultural values with the application of other interesting material / form adoption) can become SME activities in improving PI performance for business sustainability in the batik business arena and having products that not easy to imitate, according to the needs of consumers and have an advantage on the same product in SME Central Kalimantan. This study has limited data and geographical locations in Central Kalimantan which may be different in other emerging markets. However, in MO the results are significantly positive, this value is not stronger than EO for PI, so it can be further carried out from this research, about how MO for Pls with other mediations to fill gaps and answer some phenomena that refer to local SMEs for products to be able to sustainable.

\section{Acknowledgements}

Honorable Dean of the Faculty of Economics and Business, with the permission of the team in the scope and topic of our research, Small and Medium Enterprises in the creative field who have collaborated in this research and support from the official government of cooperatives and SMEs in Central Kalimantan Province.

\section{References}

Abdulai Mahmoud, M. and Yusif, B. 2012. Market orientation, learning orientation, and the performance of nonprofit organisations (NPOs). International Journal of Productivity and Performance Management, 61, pp. 624-652.

Açıkgöz, A., Günsel, A., Kuzey, C. and Seçgin, G. 2016. Functional Diversity, Absorptive Capability and Product Success: The Moderating Role of Project Complexity in New Product Development Teams. Creativity and Innovation Management, 25, pp. 90-109.

Adeniran, T. V. and Johnston, K. A. 2012. Investigating the dynamic capabilities and competitive advantage of South African SMEs. African Journal of Business Management, 6, pp. 4088-4099.

Adhikari, A. and Gill, M. S. 2011. Impact of resources, capabilities and technology on market orientation of Indian B2B firms. Journal of Services Research, 11 (2), pp. 75-98.

Affendy, A.H., Asmat-Nizam, A.-T., Farid , M.S. 2015. Entrepreneurial Orientation Effects on Market Orientation and SMEs Business Performance - A SEM Approach. Society of Interdisciplinary Business Research, 4 (3), pp. 259-271.

Al-Dhaafri, H. S. and Al-Swidi, A. 2016. The impact of total quality management and entrepreneurial orientation on organizational performance. International Journal of Quality \& Reliability Management, 33, pp. 597-614.

Alireza, J., Mastura, J. \& Thurasamy, R. 2014. Entrepreneurial orientation and performance: the interaction effect of customer capital. World Journal of Entrepreneurship, Management and Sustainable Development, 10, pp. 48-68.

Aljanabi, A. R. A. 2018. The mediating role of absorptive capacity on the relationship between entrepreneurial orientation and technological innovation capabilities. International Journal of Entrepreneurial Behavior \& Research, 24, pp. 818-841.

Amin, M., Thurasamy, R., Aldakhil, A. M. and Kaswuri, A. H. B. 2016. The effect of market orientation as a mediating variable in the relationship between entrepreneurial orientation and SMEs performance. Nankai Business Review International, 7, pp. 39-59. 
Ata, Z. C., Zehir M 2018. The Impact of New Product Development Capability and Market Orientation on the Firm Performance: A Research in Large Scale Enterprises in Turkey. Business Management Dynamics, 8, pp. 01-12.

Augusto, M. and Coelho, F. 2009. Market orientation and new-to-the-world products: Exploring the moderating effects of innovativeness, competitive strength, and environmental forces. Industrial Marketing Management, 38, pp. 94-108.

Baker, T. L., Cronin Jr, J.J., Hopkins, C.D., 2009. The impact of involvement on key service relationships. Journal of Services Marketing, 23, pp. 114-123.

Balodi, K. C. 2016. Configurations and entrepreneurial orientation of young firms: revisiting theoretical specification using crisp-set qualitative comparative analysis. Management Decision, 54 (4), pp. 1004-1019.

Bauer, M. and Auer-Srnka, K. J. 2012. The life cycle concept in marketing research. Journal of Historical Research in Marketing, 4, pp. 68-96.

Beneke, J., Blampied, S., Dewar, N. and Soriano, L. 2016. The impact of market orientation and learning orientation on organisational performance: A study of small to medium-sized enterprises in Cape Town, South Africa. Journal of Research in Marketing and Entrepreneurship, 18, pp. 90-108.

Boso, N., Cadogan, J. W. and Story, V. M. 2012. Entrepreneurial orientation and market orientation as drivers of product innovation success: A study of exporters from a developing economy. International Small Business Journal, 31, pp. 57-81.

Boso, N., Story, V. M., Cadogan, J. W., Annan, J., Kadić-Maglajlić, S. and Micevski, M. 2016. Enhancing the sales benefits of radical product innovativeness in internationalizing small and medium-sized enterprises. Journal of Business Research, 69, pp. 5040-5045.

Brashear, T., Bicen, P. and Hunt, S. D. 2012. Alliance market orientation, new product development, and resource advantage theory. Journal of Business \& Industrial Marketing, 27, pp. 592-600.

Carbonell, P. and Rodríguez Escudero, A. I. 2010. The effect of market orientation on innovation speed and new product performance. Journal of Business \& Industrial Marketing, 25, pp. 501-513.

Caseiro, N. and Coelho, A. 2018. Business intelligence and competitiveness: the mediating role of entrepreneurial orientation. Competitiveness Review, 28, pp. 213-226.

Chahal, H., Dangwal, R. C. and Raina, S. 2016. Marketing orientation, strategic orientation and their synergistic impact on business performance: A case of SMEs in emerging context (India). Journal of Research in Marketing and Entrepreneurship, 18, pp. 27-52.

Chen, X., Chen, A. X. and Zhou, K. Z. 2014. Strategic orientation, foreign parent control, and differentiation capability building of international joint ventures in an emerging market. Journal of International Marketing, 22, pp. 30-49.

Chen, Y.-C., Li, P.-C. and Evans, K. R. 2012. Effects of interaction and entrepreneurial orientation on organizational performance: Insights into market driven and market driving. Industrial Marketing Management, 41, pp. 1019-1034.

Day, G. S. 2000. Managing market relationships. Academy of Marketing Science Journal, 28, pp. 24-30.

Deniz, K. 2016. Strategic entrepreneurship: mediating the entrepreneurial orientation-performance link. Management Decision, 54, pp. 24-43.

Dilger, M. G., Jovanovic, T. and Voigt, K. I. 2017. Upcrowding energy co-operatives Evaluating the potential of crowdfunding for business model innovation of energy co-operatives. Journal of Environmental Management, 198, pp. 50-62.

Ejdys, J. 2015. Market orientation vs. inovativeness of SMEs of Podlaskie province. Verslas: Teorija ir Praktika, 16, pp. 353-361.

Fernandez-Mesa, A., Alegre-Vidal, J., Chiva-Gomez, R. and Gutierez-Gracia, A. 2013. Design management capability and product innovation in SMEs. Management Decision, 51 (3), pp. 547-565. 
Hair, J. F., Black, W. C., Babin, B. J. and Anderson, R. E. 2010. Multivariate Data Analysis, Prentice Hall.

Hair, J. F., Ringle, C. M. and Sarstedt, M. 2011. PLS-SEM: Indeed a Silver Bullet. The Journal of Marketing Theory and Practice, 19, pp. 139-152.

Han, J. K., Kim, N. and Srivastava, R. K. 1998. Market orientation and organizational performance: is innovation a missing link? The Journal of Marketing, 62 (4), 30-45.

Haryanto, H., Sawitri 2017. Market Orientation, Learning Orientation and Small Medium Enterprises Performance: The Mediating Role of Innovation. International Review of Management and Marketing, 7, pp. 484-491.

Inic, B. P. and Petrovic, Z. M. 2012. The influence of service-dominant orientation of small firms on its growth. African Journal of Business Management, 6, pp. 11202-11205.

Jalilvand, M. R., Nasrolahi Vosta, L., Khalilakbar, R., Khazaei Pool, J. and Tabaeeian, R. A. 2019. The Effects of Internal Marketing and Entrepreneurial Orientation on Innovation in Family Businesses. Journal of the Knowledge Economy, 10 (3), pp. 1064-1079.

Jin, B. and Cho, H. J. 2018. Examining the role of international entrepreneurial orientation, domestic market competition, and technological and marketing capabilities on SME's export performance. Journal of Business \& Industrial Marketing, 33, pp. 585-598.

Jin, B., Jung, S. and Jeong, S. W. 2017. Dimensional effects of Korean SME's entrepreneurial orientation on internationalization and performance: the mediating role of marketing capability. International Entrepreneurship and Management Journal, 14, pp. 195-215.

Kocak A, C. A., Oflazoglu 2017. Market, entrepreneurial, and technology orientations: impact on innovation and firm performance. Management Decision, 55, pp. 248-270.

Line, N. D. and Wang, Y. 2016. A multi-stakeholder market oriented approach to destination marketing. Journal of Destination Marketing \& Management, 6 (1), DOI: 10.1016/j.jdmm.2016.03.003.

Morgan , T., Anokhin , S. and Wincent, J. 2016. Entrepreneurial orientation, firm market power and opportunism in networks. Journal of Business \& Industrial Marketing, 31, pp. 99-111.

Newman, A., Prajogo,Altherton 2016. The influence of market orientation on innovation strategies. Journal of Service Theory and Practice, 26, pp. 72-90.

Ngo, L. V. and O'cass, A. 2012. In search of innovation and customer-related performance superiority: The role of market orientation, marketing capability, and innovation capability interactions. Journal of Product Innovation Management, 29, pp. 861-877.

Nuryakin 2018. Competitive Advantage and Product Innovation:key success of batik smes marketing performance in Indonesia. Academy of Strategic Management Journal, 17 (2), https://www.abacademies.org/articles/competitive-advantage-and-product-innovation-key-s uccess-of-batik-smes-marketing-performance-in-indonesia-7164.html.

Ozkan-Canbolat, E., Beraha, A. and Bas, A. 2016. Application of Evolutionary Game Theory to Strategic Innovation. Procedia - Social and Behavioral Sciences, 235, pp. 685-693.

Pan, X. and Li, S. 2016. Dynamic optimal control of process-product innovation with learning by doing. European Journal of Operational Research, 248, pp. 136-145.

Pitchayadol, P., Hoonsopon, D., Chandrachai, A. and Triukose, S. 2018. Innovativeness in Thai family SMEs: An exploratory case study. Journal of Small Business Strategy, 28, pp. 38-48.

Setyanti, S. W. L. H., Troena, E. A., Nimran, U. and Rahayu, M. 2013. Innovation Role in Mediating the Effect of Entrepreneurship Orientation, Management Capabilities and Knowledge Sharing Toward Business Performance: Study at Batik SMEs in East Java Indonesia. Journal of Business and Management, 8 (4), 16-27.

Sharma, P., Davcik, N. S. and Pillai, K. G. 2016. Product innovation as a mediator in the impact of R\&D expenditure and brand equity on marketing performance. Journal of Business Research, 69, pp. 5662-5669. 
Siringoringo, H., Margianti, E. S., Kowanda, A. and Saptariani, T. 2013. Shopping Behavior of Indonesian Consumer Towards Imported Products. Procedia - Social and Behavioral Sciences, 81, pp. 411-415.

Sok, P. and O'cass, A. 2015. Examining the new product innovation - performance relationship: Optimizing the role of individual-level creativity and attention-to-detail. Industrial Marketing Management, 47, pp. 156-165.

Teece, D. J., Pisano, G. and Shuen, A. 1997. Dynamic Capabilities and Strategic Management Strategic Management Journal, 18, pp. 509-533.

Tohidi, H. and Jabbari, M. M. 2012. Product Innovation Performance in Organization. Procedia Technology, 1, pp. 521-523.

Vega-Vázquez, M., Cossío-Silva, F.-J. and Revilla-Camacho, M.-Á. 2016. Entrepreneurial orientation-hotel performance: Has market orientation anything to say? Journal of Business Research, 69, pp. 5089-5094.

Wong, S. K.-S. 2012. The influence of green product competitiveness on the success of green product innovation Empirical evidence from the Chinese electrical and electronics industry European Journal of Innovation Management, 15 (4), pp. 468-490. https://doi.org/10.1108/14601061211272385.

$\mathrm{Wu}$, J. 2013. Marketing capabilities, institutional development, and the performance of emerging market firms: A multinational study. International Journal of Research in Marketing, 30, pp. 36-45.

Yang, F. and Yang, M. 2015. Analysis on China's eco-innovations: Regulation context, intertemporal change and regional differences. European Journal of Operational Research, 247, pp. 1003-1012.

Yu, X., Nguyen, B. and Chen, Y. 2016. Internet of things capability and alliance: Entrepreneurial orientation, market orientation and product and process innovation. Internet Research, 26, pp. 402-434.

Yuan, L. and Chen, X. 2015. Managerial learning and new product innovativeness in high-tech industries: Curvilinear effect and the role of multilevel institutional support. Industrial Marketing Management, 50, pp. 51-59.

Zhang, H., Zhang, T., Cai, H., Li, Y., Huang, W. W. and Xu, D. 2014. Proposing and validating a five-dimensional scale for measuring entrepreneurial orientation: An empirical study. Journal of Entrepreneurship in Emerging Economies, 6, pp. 102-121.

Zohdi, M., Shafeai, R. and Hashemi, R. 2013. Influence of relational capabilities on Business performance Case of: Kermanshah industrial city SMEs. International Research Journal of Applied and Basic Sciences, 4 (3), pp. 589-596.

\section{Bio-note}

Kristinae, Master of Science, is a lecturer at Palangkaraya University, Faculty of Economics and Business. Researchers with teams developed in projects implemented by our Faculty in the field of marketing management and small and medium sized enterprises, entrepreneurship in Central Kalimantan, Indonesia.

Sambung, Doctor of Philosophy, is a lecturer at Palangkaraya University, Faculty of Economics and Business. Researchers with teams developed in projects carried out by our Faculty in the field of human resource management and small and medium sized enterprises, entrepreneurship in Central Kalimantan, Indonesia

Sahay, Doctor of Philosophy, is a lecturer at Palangkaraya University, Faculty of Economics and Business. Researchers with teams developed in projects carried out by our Faculty in the field of marketing management and small and medium sized enterprises, entrepreneurship in Central Kalimantan, Indonesia. 